\title{
TURTLE (DEMON OR GUARDIAN) \\ A STUDY IN PARTICULAR MAGICAL WANDS
}

\author{
WAEL SAYED SOLIMAN \\ SINAI HIGH INSTITUTE OF TOURISM, EGYPT
}

\begin{abstract}
The Ancient Egyptians believed Turtle was capable of harm and help, it occupy a clear important place within the Ancient Egyptian demonology, as a turtle-demon and a turtle-guardian. During the Middle Kingdom, Turtle-demons were depicted on objects especially wands. While, later during the Late and Greco-Roman periods we begin to note an enlarging of some apotropaic gods whose special mission is to control the aggressive powers of demons. Turtle is comprised of those guardians who keep watch over the deceased on the coffins, or even in the form of statues of turtleheaded guardians.

This article is based on a set of wands, some of them found in tombs may have been specially made to protect the deceased, and to be used to defend himself against demons using the large number of the creatures among them are turtles. This procession of demons is held mythological responsible for stranding the Solar-barque in the Nile River.
\end{abstract}

KeYwORDS: Turtle, Demon, Guardian, Wand, Middle Kingdom

\section{INTRODUCTION}

Among the different depicts connected with the magic In religious practice of ancient Egyptians from the Middle Kingdom Period until later times, a special focus should be on representations of turtles on the magical wands among a numerous fearsome deities always decorated those objects which were widely served as amulets for mothers and small children.

A specific aspect of Middle Kingdom Egyptian apotropaia, inscribed ivory wands, is connected by its religious, magical, and mythological connotation. The exact function of these objects is of great interest, while the focus of this article will be on the different role that both turtle-demon and turtle-guardian play through the Egyptian history, not only on wands but also on different kind of monuments, a fuller picture of these multifaceted entities may emerge.

There are hundreds of ivory apotropaic wands in museum collections around the world. The analysis for this article is based on a set of fifteen wands. Very few have good provenance, but there is enough evidence to 
show that wands of this type have been reserved a good area for the turtle figure. It is a difficult task to trace the development of this animal depiction. Due to their variety, wide meaning and lack of classical form, this attempt can only be made without any clear answer.

\section{TURTLES}

It is well known that Ancient Egyptians regarded the animal world with massive interest. This concern originated in respect, inquisitiveness, protection, wonder, love, trust, appreciation, confusion and fear that animal behaviors and features might incite them. It is therefore natural that most of the Egyptian forms of expression included accurate representations of the turtles which lived at that time in the different environments of the Nile Valley and beyond. They respect the turtle exactly like many other Ancient Civilizations, due to its crumpled appearance, strength, slow movement, and long lifespan; it is a sign of solidity, sedentary and longevity in many cultures (Becker, $1994 \&$ Cirlot, 2002).

In many cases, the scenes of the turtle reproduced on monuments, especially the magical tools, were actually focused on animals, or on any realistic and imaginary form of interaction between animals and human beings. The correct knowledge of the status of these tools and iconography (wands, stelae, rods, cups and others) has been for long time a matter of scholarly debates.

Today there are about 250 species with 11 families of turtles and tortoises worldwide (Rittner, 2004). It is belongs to that class of cold-blooded vertebrate hibernation reptilian animals. While, the Egyptian turtles commonly dwell in deserts, sea coasts, River Nile and its valley. We could divide these three kinds of turtles into two main types, the first is the Land Tortoise ${ }^{1}$ Testudo kleinmanni and the second is Aquatic Turtle (separated into both the River Nile Turtle or Trionyx triunguis, and the Red Sea Turtle or Chelonia Imbricata). The first type is the high-domed carapace turtle which classified Loveridge and Williams, as reptiles, their size and colour are perfect for the dry arid climates in the desert, light shelled tortoise able to blend in and keep cool through the heat in the day (Loveridge, 1957). ${ }^{2}$ The males' features are different from the females. However the second type, is the leathery carapace turtle, which is still less populated area of Sudan (Fischer, 1986) and other African countries; one of its main features

\footnotetext{
${ }^{1}$ Many of the terrestrial turtles are called tortoises.

${ }^{2}$ For more information about the tortoise see: Christoph, S. \& Willi, S. (2008). "The Egyptian Tortoise, Testudo kleinmanni Lortet, 1883 in Libya," Salamandra - German Journal of Herpetology, vol.44, no.3, Berlin, 141-152.
} 
is the long tubular nose that it protrudes above the water when it breaths (Carr, 1952).

Names of the turtle-animal are fairly well known owing to the hieroglyphic inscriptions accompanying the paintings, but they are rather vague: for instance the word Turtle had two different expressions, Stw (Faulkner, $1977)^{3}$ and $S t A$. The generic word for the animal was o , ए $28,5 t w,{ }^{4}$ but sometimes (especially on the astronomical texts, on which usually represented as pair of it refer to a Decan) named \& Styw. ${ }^{5}$ There is also another word gives the same meaning which is $S t A$, that probably derived from $S t A$ 'secret, hidden, or mysterious', ${ }^{6}$ referring to the vanishing of turtle under the water of the river and being hidden in the mud (Walle, 1953). Both the two words $S t A$ and $S t$ used later alongside Stw to identify the animal during the Late Period (Kitchen, 1993); while in the Greco-Roman Period they keep using ש8 (Cauville, 2001); var.

It also appeared with a fish determinative $\square$ i I Stw, shows that the Ancient Egyptians classified the animal as a kind of fish. It seems that because Trionyx an inhabitant of the aquatic environment has a soft shell, the ancient Egyptians integrated into fish. The Egyptians also used more names for the same animal as:

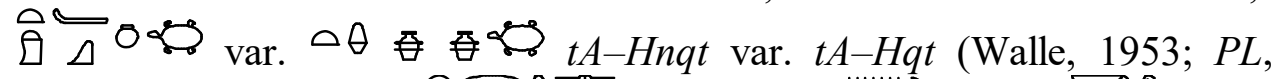

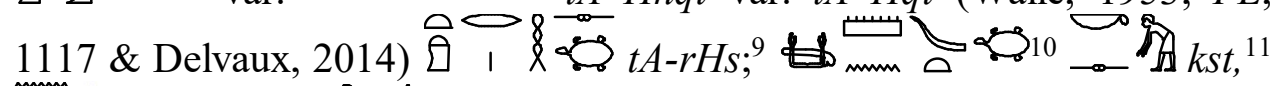

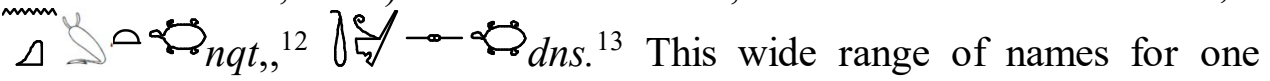

\footnotetext{
${ }^{3}$ Faulkner suggested that the word had come from the same root $S T$ 'tortoise' to cover oneself up (to hide or to make secret) like a tortoise.

${ }^{4} \mathrm{~Wb}$ IV $, 557,6$.

${ }^{5} \mathrm{ME}, \mathrm{p} .273 ; \mathrm{Wb} \mathrm{IV}, 556$.

${ }^{6} \mathrm{ME}, 272 ; L E$, vol.2, 138; $W b \mathrm{IV}, 272$.

${ }^{7} P L, 1034$.

${ }^{8} P L, 1076$. The term is used in turtle slaying rituals. Walle suggested that $m n x$ was driven from imnx 'to butcher'. Walle, B. Van de, 185.

${ }^{9} P L, 1117$.

${ }^{10} \mathrm{~Wb} \mathrm{~V}, 96$.

${ }^{11} P L, 1091$

12 PL, 552.

${ }^{13} \mathrm{~Wb} \mathrm{~V}, 469$; PL, 1200-1.
} 
kind of animals shows the great role turtle played in the Egyptian society till the Greco-Roman Period.

\section{SATANIC SYMBOL}

In many Ancient civilizations, turtle was thought of as a demonic animal that stood in association with dark powers; depictions it as a symbol of darkness in battle with light (Becker, 1994). As a scavenger that prowled in deep water, the turtle was considered sinister and unclean, dangerous to the living and enemy of the gods, but it was often appealed in magic. Among many spells for safety upon the river, a spell on a Hieratic papyrus reads: "A spell for fish eating or turtles" (Gardiner, 1944). Parts of their bodies like shells and gall-bladder (Borghouts, 1978) were used in a big collection of magical spells.

It occupied a part of the magical tools, jewellery, and even children's drinking cups, thus converting their threat into protective power. One of the names of the turtle identify it as 2 var.

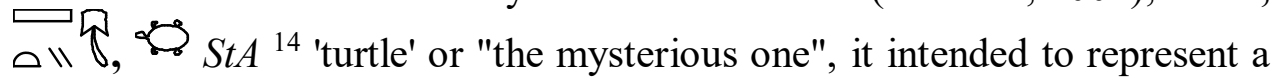
creature of evil symbolizing death and darkness, probably due to its waterbased reality, it was believed to inhabit the foggy waters of the Underworld, waiting to impede the nightly progression of the Sun God's bark

Among the earliest examples that represent the animal as a monster or demon, is a pry-dynastic cosmetic palette that apparently represents a twoheaded turtle (fig.2) (Fischer, 1966). As late as $1^{\text {st }}$ Dynasty, its figurines is probably to be recognized in the absence of the eyes, in a kind of intended damaged, and appeared on many statues, amulets, turtle-vessels, as well as turtle-palette and dishes (Fischer, 1968). That damage has been purposely blinded to extract the animal helpless.

It seems that starting from the Middle Kingdom when the Ancient Egyptians escaped turtle-flesh from their diet which could be because of an outbreak of salmonellosis ${ }^{15}$ was traced to the Nile Turtle during that time. Likewise because it is flesh-eating dangerous animal and grows to so formidable a size that it is capable of imposing serious wounds if not handled with great respect (Fischer, 1966), and to be able to eat small Nilotic creatures. So fell under inquisitive forbidding, the matter that needs more clarification. Unfortunately, all the three kinds of turtles that dwell

\footnotetext{
${ }^{14} P L, 1034$.

15 For more information see: Mitchell, A. \& Simon M. S. (January 2001). "Salmonella in Reptiles Mark," Seminars in Avian and Exotic Pet Medicine, vol.10, no.1, Philadelphia, 25-35.
} 
Egypt never mentioned in an offering list of any kind, but this elimination is inconclusive since fish, which were eaten at all periods, are not mentioned either (Bates, 1917), it certainly indicates that they were considered to be ritually infected.

The Coffin Texts, show that the relation between the Egyptians and the creature switched from respect to fear, in a spell protecting the deceased against the possibility of having to eat excrement in the next world, "If you tell me to eat this, then Ra will eat turtle" (De Buck, 1961). ${ }^{16}$ This relationship brought it into disagreement with the powerful sun god Ra, who was obliged to pass beneath its dark domain on his dangerous journey during the night. Spell 173 was entitled as "Not to walk upside down". The association of the turtle with this theme was probably born from the ability of this species to get back on its feet when it finds itself on its back, this thanks to the flexibility of its slightly convex shell, whereas most Land turtles, with more rigid, rounded shells, have more difficulty standing up. The fear of having to "walk upside down" is encountered several times in funerary literature, since the Pyramid Texts (Gutbub, 1979).

By the New Kingdom, A number of demons occupied a part of the Afterlife books, especially Book of the Dead spells, that decorated some of the papyri, temples, and tombs in the Valleys of the Kings and Queens, where we could analysed that the function of these demons as guardians. The sun god's opposition between $\mathrm{Ra}$ and the turtle was even more strongly framed in the Spell 161 of the Book of the Dead which carved a sarcophagi and funerary papyri till the Late Period, reads: "May Re live and may the turtle die" (Allen, 1974). It became one of the forms and associated with Apophis the main enemy against $\mathrm{Ra}$, who tried to stop his solar barque, as a subject to ritual extermination. This ritual is mainly directed against the hateful turtle Apophis himself, but also against other animals, like serpent, hippo and other creatures. It is also noticeable in the Book of the Dead spell 83, in which in a solar transformation the deceased "assumes the form of a phoenix" (Andelkovic, 2015).

Compendium of magical rituals preserved in Papyrus Bremner-Rhind which dates back to the $19^{\text {th }}$ Dynasty clarified that association with Apophis, specifically in the 'Book of Overthrowing Apophis.' The turtle is used as a determinative connected to the name of Apophis

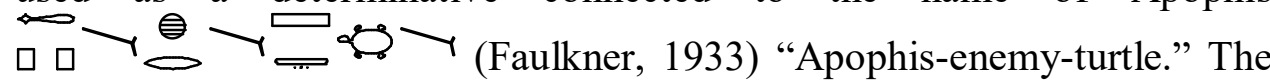
association appears in a list of the names of Apophis that shall not be.

${ }^{16}$ For more information see: Walle, B. Van de, 173-189; Vermis, P. (1990). Future at Issue. Tense, Mood and Aspect in Middle Egyptian: Studies in Syntax and Semantics, New Haven, 90, no.159. 
As an enemy of Ra, a kind punishment was inflicted at some period after the turtle ceased to be represented (Fischer, 1966). Spearing the turtle is first depicted in a tomb as early as the $19^{\text {th }}$ Dynasty (fig.1), where the deceased is pictured harpooning a turtle (Säve-Sőderbergh, 1956), accompanied by the familiar previously formula which often repeated on sarcophagi of the New Kingdom. The same scene spread through history until the Greco-Roman Period. The ritual of the spearing is often found in scenes concerned with killing Apopis in the form of a crocodile or an oryx, Hitting the Ball, and the offering of pieces of a slaughtered enemy (Borghouts, 1973); occur in these late period temples. I do not agree with Hornung who suggests that, although ritual scenes of 'Spearing Apophis' arise only in Ptolemaic and Roman temples, but there are various actions against Apophis that come down from earlier sources (Hornung, 1956).

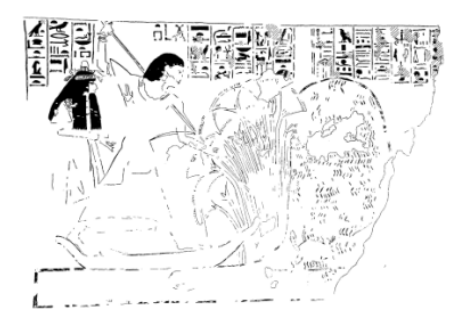

Fig.1: The deceased harpoon the turtle, tomb T157 of Nebunenef, Luxor, 19 ${ }^{\text {th }}$ Dynasty.

cf. Fischer, H.G. Ancient Egyptian representation of turtles, fig.3.

By the Greco-Roman Period the termination of turtles along with other demonic creatures is often represented. Reliefs in many temples show the turtle being ritually speared by the king, and there is reason to think that models of papyrus or wax were smashed by the king's priestly representatives who enacted his role (Fischer, 1966).

\section{TURTLE-DEMON}

Ancient Egyptian demonology is in general related to earlier religious beliefs, as attested in the magical and ritual texts and iconography of the Old Kingdom to the Late Period. They also continued to be thought of being beneficial powers up until the Greco-Roman Period. As early as the pre-dynastic period, scenes depicting demons were carved on royal artifacts, like ceremonial slate palettes, ivory plaques and ivory knife handles. A clear example is the famous Narmer palette (Fischer, 1987), where the mythical animal Serpopard ${ }^{17}$ appeared with a lion's body, a very long snake's neck and a leopard head. There were curiously absent of

${ }^{17}$ This animal was regularly depicted on magical wands with a serpent in its mouth. 
Demons from Old Kingdom tomb decorations, and there is not so very apparent in the Pyramid Texts, although they contain some frightening concept such as a curse against damages or robs the tomb and will be convicted himself, or against the follower of Seth (Pyrs.1285c-1286.) (Sethe, 1908). Among the troops of demons that appeared for the first time (name not iconography) are the Slaughterers $x$ Atyw (Meeks, 2001).

Later during the Middle Kingdom, demons were depicted on objects such as wands, statues, coffins and even the wall scenes of the local governors at Meir, Bersheh and Beni Hassan especially that illustrating desert hunting scenes (Kanawati, 2010). Those demons made their debut in the Early Dynastic and survived down to the Greco-Roman Period. Different kinds of demons appeared in the Coffin Texts, especially those who hunted the souls of the dead. They appeared as part of the Book of the Two Ways (Lesko, 1972) and other Guides of the Netherworld, are main sources of demonic creatures, most of which play the role of doorkeepers.

During the New Kingdom, they occupied a part in the Book of the Dead, which was populated by names and epithets of big number of demons, recorded on a variety of tomb walls, papyri and funerary objects. It was sometimes used as amulets to protect the wearer against demons. They are often depicted as animals holding knifes, functioned as watchers of doors and gates. They rarely have names but instead are known by epithets that describe their nature as: 'Swallower of Shadows,' 'Big and Fiery,' 'God who lives on meat-sacrifice,' 'who swallows shadows,' 'who snatches hearts,' and other different epithets (Szpakowska, 2009).

During the Late Period, there arises a tendency to explain all kinds of unlucky happenings by reference to some evil demonic influence on mankind, so that we can speak of a demonization of everyday life. In the same period, foreigners entering Egypt (mainly the Assyrians) begin to be represented more strongly and clearly as invaders (Lucarelli, 2011). They were believed to be disease-bringers and certain diseases, especially concerning the skin, like leprosy, were considered to be of foreign origin and were given Semitic names. These kinds of diseases seem to have been spreading in Egypt over the Late Period, perhaps from other cultures, and in the so-called "OAD" 18 they have foreign names and are listed together with a series of other dangerous beings (evil spirits, the damned dead, and ghosts) to be warded off (Lucarelli, 2011). A text dating back to the GrecoRoman Period from the temple of Esna, the entrance of those affected by kind of diseases is forbidden through a special formula (Koenig, 2004).

18 The "OAD" or "Oracular Amuletic Decrees" consisted in strips of papyrus inscribed with magical spells, brought on the neck as amulets by the new born. They produced at Thebes during the first part of the Late Period. 
Because of the supernatural power of the demons, some of them became especially popular gods. Moreover, it is interesting to note that some of the occurrences of the term $n T r w$, indicating both benevolent and malevolent demons, occur particularly in the magical, medical and ritual texts of the Late Period and even more during the Greco-Roman period (Lucarelli, 2009). During this period, demons take place in iconographic and textual sources, decorating tombs and temple walls, especially in the Ptolemaic Period. Figures made of fired clay were popular in Egypt during the GrecoRoman period. Their main purpose was to protect family from demons that plagued them. During this Period, a big number of magical papyri were illustrated by demons, deities and magical formulae.

\section{WANDS}

There are a big number of magical wands in museum collections around the world, easily recognizable due to their distinctive shape and decoration. These objects have enough evidence to show the role turtle played amongst the demons. It was used during the life of the Egyptians, so wear, crack, fracture and repairs occurred.

They are kind of flat curved objects, usually made of hippopotamus ivory ${ }^{19}$ which naturally gives them their distinctive curved shape, ${ }^{20}$ usually between 25 and $35 \mathrm{~cm}$ long that have been intended to provide a relatively flat surface for decoration. They are decorated with some of the earliest representations of a whole range of supernatural creatures (demons) and divine manifestations (Pinch, 1994), and frequently inscribed also with texts. They are wrongly called "magical knives" by some writers, which is a far topic from what they use for, ${ }^{21}$ or, perhaps more appropriately, "apotropaia" (Altenmüller, 1965). ${ }^{22}$

Wands appeared for the first time during the Middle Kingdom in the Eleventh Dynasty (Altenmüller, 1965; Roberson, 2009 \& Szpakowska,

\footnotetext{
${ }^{19}$ Ivory placed the formidable power of the hippopotamus in the hand of the magician, according to Pinch. Pinch, G. (1994). Magic in Ancient Egypt, British Museum Press, London, 40.

${ }^{20}$ The shape may be derived from a type of throw-stick used against birds. Flocks of wild birds were a symbol of the forces of chaos in Egyptian art, so the throw-sticks used to kill or stun them, or the clap-nets used to catch them, could symbolize the victory of order over chaos. In private magic they were emblems of the control a magician hoped to exercise over demons. Pinch, G. 40.

21 Wands have no cutting edge, practical or vestigial, and actually bear no resemblance at all to Egyptian knives.

22 "Apotropaic" according to Pinch means something that turns away evil, particularly evil spirits. Pinch, G. 40 .
} 
2009), performed in the material record primarily between 2000 and 1600 $\mathrm{BC}$. in a period corresponding roughly to the latter half of the $11^{\text {th }}$ Dynasty through the $17^{\text {th }}$ Dynasty (Altenmüller, 1965 \& Roberson, 2009). Indeed, they were common features in this period' burials, generally used as magical tools designed to turn away evil influences. Studying the existing archaeological evidence suggests that no context is earlier than the late Middle Kingdom. From New Kingdom backgrounds, finds of heavily damaged fragments represent use of damaged material either worn by continual use, or, perhaps most likely, discovered during reuse of tombs containing late Middle Kingdom burials (Miniaci, 2009), like in the case of the wand (no.13).

It is connected chiefly through its iconography and symbolic connotation, which in many respects can be traced to the Predynastic Period of Egypt's history. Its popularity in the Middle Kingdom can be explained by the expansion of the Egyptian empire, by a renewed concern with social issues current in the Predynastic, and by an increase in personal piety that fostered the development of amulets and apotropaic rituals (Hackley, 2014). Likewise, some scholars (Wegner, 2009 \& Hackley, 2014) reasoned it's appearing in this period to the larger trend toward personal religion and domestic cult activity, following the political breakdown of the First Intermediate Period when the common people were beginning to negotiate their own relationships with divinities, as evidenced by the increase in amulets and ritual paraphernalia in private contexts.

The wand are characterized by this selection of apotropaic demons who all seem to have had the general name of $n T r w$ 'gods,' $a H A \mathrm{w}$ 'fighters' and $s A w$ 'protectors' (Pinch, 1994) according to the inscriptions held on it. Its purpose is exposed by one of those inscriptions carved a wand in the Metropolitan Museum of Art reads: "reading by the many protectors: we have come that we may spread our protection around the healthy child Minhotep, alive, sound, and healthy, born of the noblewoman Sitsobek, alive, sound, and healthy." Two more in the same museum inscribed on with the words "protection by day and by night."23

Actually, there is no term exists to identify Egyptian demons but they are often called $n T r$ or $n T r t$ "god-category," but clearly not in the same category as gods who have names and cults. They are usually understood by Egyptologists as "minor divinities", assistants to superior powers, or agents of chaos and evil. However, Hackley believes that these figures derive originally foreign influences were potential agents of chaos,

\footnotetext{
${ }^{23}$ Wands cat. nos. 20, 21 and 22. in the Metropolitan Museum of Art. Allen, J.P. (2005). The Art of Medicine in Ancient Egypt, Metropolitan Museum of Art, New York, 29.
} 
destruction, and upheaval, threatening to the laws of Maat, or cosmic balance (Hackley, 2014). The entrance of strangers would have inspired a certain amount of anxiety in a culture comfortably contained by the Egyptians. Foreign animals and people had long been used as iconographic shorthand for menacing forces the king of Egypt needed to subdue and control.

These demons or "genii," according to Szpakowska, are fully armed with traditional weapons such as knives, spears, and daggers (Szpakowska, 2009). They were also helped to guard humans ${ }^{24}$ on earth from those demons who have come over to assault them from the afterlife. In these cases their power could be activated by carving or drawing their images onto apotropaic devices. Some of these artifacts were the wands which specifically designed as magical implements to protect vulnerable individuals (Szpakowska, 2009 \& 2011). Some of them were beasts and monstrous beings wandering out the desert that was considered an unpredictable messy landscape.

In general they all appear to be connected to events occurring in the Netherlands. Some other writers believe that the processions of creatures on the wands depict a very specific mythological moment, the return of the Solar Eye of Re from her stay in the south-eastern desert (Hackley, 2014), and protected the newborn Sun God (Roberson, 2009) on his dangerous journey through the night-time sky. They reference this important mythological event in ways that illustrate the importance of the myth in the cultural landscape of the Middle Kingdom Egyptians. While, another opinion believes that it seem to have been associated with acts of ritual magic in which the king overcame the enemies of Egypt (Pinch, 1994).

Some initial scholars (Legge, 1905 \& Murray, 1906) thought that wands were used mainly for a specific purpose of protection against the bites of the snakes perhaps other misfortunes. While, previous writers ${ }^{25}$ seem that they were carried by some magicians as symbols of their authority to summon and control the powerful beings or the so called fearsome deities (demons). But this kind of ritual magical method was actually used for more widely protected functions. The party to be sheltered is quite varied, either a woman or a child, it is also used by the deceased.

The purpose of these wands was not only to provide protection against the dangers of everyday existence, such as scorpions and poisonous snakes, but also to protect against illness and accidents, difficult births, nightmares, and the fear of the unknown. While, most of them, it seems, belonged to

\footnotetext{
${ }^{24}$ Petrie also agreed with this opinion that they were for the benefits of the living, and not for the dead. Petrie, W. M. F. (1927). Objects of Daily use, London, 41.
}

${ }^{25}$ Like Pinch, G. 42. 
women and children; which explained why some of these objects show signs of wear on tips, suggesting that it was used for motherhood purposes. Perhaps the widely used of the wand as a protection method because of its original practice to protect both the young Horus and his mother Isis when they hide in the marches (Meeks, 2001). The appearances of the goddess Tawaret among the creatures (represented on wands), has led scholars to conclude that the wands had a function in childbirth or were amulets for young children and new mothers (Steindorff, 1946). Much of the imagery from the wands is also found on birth bricks and magic rods, making this connection seem very likely (Wegner, 2009).

Some of the owner women were princesses, but others seem to have been of lower social status. On a few wands with longer inscriptions, a mother and child are identified with the divine mother and the infant sun god. ${ }^{26}$ Another view about their use may have been to create a protective zone around marriage bed, pregnant women, ${ }^{27}$ or mothers with young children (Roberson, 2009 \& Wegner, 2009). Wegner suggested that a magician would draw the wand through the sand and create a protective circle around the woman to give birth or to nurse her child (Wegner, 2009 \& 2015).

These were likely used during and just after childbirth to draw a protected circle around the mother and child enclosing the vulnerable individuals within a sanctified zone that demons feared to breach (Szpakowska, 2009). They were invoking the protection of the gods that are shown on them represented eating enemies and snakes, and thus controlling evil.

Rare of the demons decorated the wands shown with human bodies, and the majority are represented with animal figures like lions, vultures, cats, baboons, bulls, turtles, snakes, scarab-beetles, flies, panthers, crocodiles, and frogs. There are also some other monsters such as the Seth animal, the griffin, a panther-like beast with an elongated neck, a double sphinx (Aker); beside some other deities as a composite hippopotamus goddess most likely Taweret, the dwarf Aha (an early form of Bes), Bastet, Heka; and finally some hieroglyphic signs. It is seldom that any two figures are found repeated together, except the commonest (Petrie, 1927).

Demons depicted on wands were always located within a 'boundary', which may appear in different variations (Vink, 2016). These boundaries could be in the form of an elliptic framing line, lion's mask and the jackal's head occupied both tips of the wand, lotus flowers and sometimes other

\footnotetext{
${ }^{26}$ Some of the entities shown on the wands appear in myth as the protectors of the sun god or of Horus and Isis in the marshes. Pinch, G. 42.

${ }^{27}$ Pinch suggested that such wands were laid on the stomach of a pregnant woman to protect the unborn child. Pinch, G. 130.
} 
demons. The duplication of figures on a single piece appears to have been deliberately avoided and, with very few exceptions, the images to be organized into one register, moving single file from one end of the wand to the other (Altenmüller, 1965 \& Roberson, 2009). In general, the processions of the figures may march in either direction along the wand, or toward the center from either end.

Turtles among those demon motifs are engraved on the magical wands that are a product of Middle Kingdom. On these wands the turtle introduces or dismisses a procession of creatures amassed for a common purpose, to ward off evil, particularly were intended to protect the women and children of a house-hold. The significance of these animals may simply be symbols of the riverine environment and the flood. Turtle-demons appear on 10\% of the discovered magical wands, but make up only $1 \%$ of the figural amethyst corpus (Hackley, 2014). It occupies a place with a number of fifteen fragments; among them is one (no.10) dating back to the $13^{\text {th }}$ Dynasty, and fourteen for the Middle Kingdom. All objects are referenced and classified in the next record; as following:

\section{Table 1: wands}

-Wand $1(\mathrm{pl} .1 .1)^{28}$

It appears exactly after uncertain damage figure on the tip, and follows the double bull-demon (a creature with long body, each end of which terminates in a bull's head). The carapace, legs and neck are covered with crossed network of lines. It has pointed part of the carapace at the rear (in the form of the tail).

\section{-Wand $3(\mathrm{pl} .1 .3)^{30}$}

The wand was broken by the owner and then lashed together with leather cords attached through drill holes on both sides of the fault-line
-Wand $2(\text { pl.1.2) })^{29}$

It was found at Lisht. The turtle occupied the regular place of the lion's mask on the tip of the tusk, and followed by frog-demon seated atop the hieroglyph $n b$. The carapace represents stippled realistically to the nature of the animal.

-Wand $4(\text { pl.1.4) })^{32}$

This fragment was found in the tomb of Neferhotep at Drah Abu'l Neggah. The turtle occupied the regular place of the jackal's mask on

\footnotetext{
${ }^{28}$ It is now in the Metropolitan Museum of Art (no.19.2.I8).

${ }^{29} \mathrm{It}$ is now in the Metropolitan Museum of Art (no.22.1.154).

30 It is mistakenly mentioned by Hackley place in the Metropolitan Museum (no.26.7.1288). Hackley, L. D. 86, no.8.
} 
to keep the parts together. ${ }^{31}$ The turtle occupied the regular place of the jackal's mask on the tip of the tusk, but its orientation with reversed against the procession. It follows a demon in the form of a sun-disc on human legs. The carapace is covered with a crossed network of lines.

\section{-Wand $5(\mathrm{pl} .1 .5)^{33}$}

This wand particularly, its pointed end terminating is not in the usual mask but in a sort of floral design. The demons procession is ended by two interweaved snakes and one outstretched one, before them the turtle is represented followed by a scarab. The carapace is covered with crossed network of lines, while the feet are decorated by parallel lines.

\section{-Wand $7(\mathrm{pl} .1 .7)^{35}$}

It is found in a Middle Kingdom tomb called 'ivory boy' beneath the store-rooms of the Rameseeum Temple. The turtle is represented following jackal's mask on the tip of the tusk, and tailed by a vulture bird of curious form bearing a flail as well as a knife. The carapace and neck are covered with crossed network of lines. It has pointed part of the carapace at the rear (in the the tip of the tusk, and was followed by an Anubis-term demon bearing a knife. The carapace is covered with crossed network of lines, while the feet are decorated by parallel lines.

-Wand $6(\mathrm{pl} .1 .6)^{34}$

It is represented on the edge of the wand surrounded by gazelle's head and a frog-demon. The carapace and neck are covered with crossed network of lines. It has pointed part of the carapace at the rear (in the form of the tail).

-Wand $8\left(\right.$ pl.1.8) ${ }^{36}$

It occupies a part in the middle of the wand behind a snake-necked panther, and in front of it is cresset or light displayed above the back of the panther. It is followed by a griffin with v-shaped wings and a human head in between the carapace and neck covered with crossed network of lines. The legs are covered with striations and each foot is tapered to a single point.

\footnotetext{
${ }^{32}$ It is now in the Egyptian Museum (JE6155 / CG 9437).

31 A complete original repair wand is preserved in only one case, now in Budapest

Museum (E.2005.1), dated back to the $13^{\text {th }}$ Dynasty.

${ }^{33}$ It is now in the Louvre Museum (N.1489).

${ }^{34}$ It is now in Berlin Museum (no.8176).

${ }^{35} \mathrm{It}$ is now in Manchester Museum (no.1800).

${ }^{36}$ It is now in the Public Museum at Liverpool (M.11001).
} 
form of the tail).

-Wand $9(\mathrm{pl} .2 .9)^{38}$

According to the procession of the demons, it seems that it lie at the beginning of the convoy. The turtle is followed by a lion standing on his back feet, with a snake emerging from his mouth. The turtel's head is damaged, while the carapace is covered with crossed network of lines.

-Wand $11(\mathrm{pl} .2 .11)^{40}$

The partly damaged turtle is represented following jackal's mask on the tip of the tusk, and tailed by a copra-snake. The carapace is covered with crossed network of lines.

\section{-Wand 13 (pl.2.13)}

It is found at Megiddo, but it seems dated back to the Middle Kingdom, not to the $18^{\text {th }}$ Dynasty like most of the monuments discovered on the site. It is located as the first demon followed the Lion's head on the tip of the wand. The carapace is represented stippled and is pointed at the rear (in the form of the tail).
Destroyed in World War Two. ${ }^{37}$

-Wand $10(\mathrm{pl} .2 .10)^{39}$

It is found in Nubian city Kerma (Sudan), and dates back to the $13^{\text {th }}$ Dynasty. It is located as the first demon followed the Lion's head on the tip of the wand, and followed by an unidentifiable demon (omitted). The turtle has a long neck and rounded feet, and the carapace is covered with crossed network of lines. It leads the procession but its orientation is reversed.

-Wand $12(\mathrm{pl} .2 .12)^{41}$

The partly damaged turtle is represented following a griffin with v-shaped wings and a human head in between, a speckled body and neck of a snake. The carapace is covered with crossed network of lines.

\section{-Wand $14(\mathrm{pl} .2 .14)^{42}$}

This fragment was found at Drah Abu'l Neggah. It occupied a part in the middle of the wand behind a snake-necked panther and a very long snake separated it from the panther. It is partly omitted, but it is clear that it has a long neck, pointed noise, and stippled carapace.

\section{$\underline{\text { Wand } 15(\mathrm{pl} .2 .15)^{43}}$}

\footnotetext{
37 This information according to the Public Museum at Liverpool. https://www.liverpool museums. org.uk / artifact/amuletic-wand-1 (Accessed on 6 November 2020).

${ }^{38}$ It is now in Brussels Museum (E7064).

${ }^{39} \mathrm{It}$ is now in Museum of Fine Art Boston (no.20.1780).

${ }^{40}$ It is now in Ftzwilliam Museum (E 394.1932).

${ }^{41} \mathrm{It}$ is now in Munich Museum.

${ }^{42}$ It is now in the Private collection of Prof. Wilhelm Spiegelberg.
} 
The fragment that remains is the blunt end of the wand, and contains the usual procession beginning in this case with the frog, which is followed by the turtle, then the hippopotamus-goddess Taweret. The representation of the turtle on this wand is quite unique, with thin legs, head and neck; also its carapace is decorated by longitudinal lines. The figure named in front of it as Stw'turtle', where the artist omitted the determinative and used the figure of the demon itself instead.

After this declaration, there are some notes about the previous group of Turtle-demons that should be mentioned. First of all, the database of this study depends on objects from museums around the world, and only three belong to private collections. The main purpose is to verify whether the turtles that appeared on the surfaces of the wands occupied a certain position among the demons procession or at random, also to clarify the role among the demons.

The demons procession is sometimes engraved on one side only, while on a few number of wands they are carved on both sides. The varied different positions of the turtle on the wand are quite regular for all the demons. It is simply dictated by reflections of space. It was regularly to represent the demons in this procession without their own attached names, but rarely did. Among those infrequently models, on wand (no.15), the name of the turtle-demon appeared as Stw 'turtle.'

Generally, the demons procession goes from the lion's mask to the jackal's head. The turtle is usually shown at the end of the demons procession on magical wands; on two wands (nos.3 and 4), it occupied the place of the jackal's mask on the tip of the tusk, located as a 'boundary', which may appear in most of the wands as lion's mask or jackal's head. Likewise five times (nos.1, 5, 7, 11, \& 15) it appeared as the last demon just before jackal's mask. Just in one case (no.2) it engaged the place of the lion's mask on the tip of the tusk, and for two times (nos.10 \& 13) it occupied the position of the first demon in the procession directly after the lion's mask which keep it from the very front.

Only in two cases (nos. 8 \& 14) where it occupied a part near the center (looks to fill a gap between two demons). Also, in two other cases (nos.6 \& 9) it appeared in random positions. In furthermost of the wands, turtle appeared horizontally and in profile as usual on most of the monuments, with only one exception on wand (no.15) where it appeared vertically and in profile figure again. It is also clear that the turtle-demon appeared two times (nos.3 \& 10) in a completely unique reversed orientation than the rest of the demons on the wands.

${ }^{43}$ It is now in the Private collection of Wilhelm MacGregor. 
In these incised representations the carapace of the turtle is frequently cross hatched, although the effect is less realistic than it is in the case of the Amulets turtle (Fischer, 1966). Those kind of realistic crossed-network pattern of the carapace in ten cases may be compared with that of a wooden figurine of the same period (Fischer, 1968). While the same style of decoration used to cover the neck of the turtle in three cases (nos.6,7 \& 8 ), and the whole body only in one case (no.1). Another two designs for the carapace appeared on the wands; one in is in the form of stippled (nos.2, 13, 14) realistically to the nature of the animal, the other as longitudinal lines (no.15). It seem that, the frequently cross-hatched carapace of the turtle has less effect than realistic with the purpose of controlling its power. The Turtle' claws are often indicted by a series of parralled lines, while its number is rarely observed very accurately.

\section{OTHER MONUMENTS}

The type of turtle iconography of demon on the wand is identical to those decorates different kind of other magical tools like the (statuettes, amulets, birth brick, feeding cup, gems and images on the magical stelae). The unique ones are representations of a votive and cultic character: magical rods and feeding cup. It is clear that the gradually declining popularity of the turtle, but abundant magical devices evidence extent during the Middle Kingdom.

The earliest representations of the turtle as an evil character, is dating back to Predynastic and Early-dynastic periods, in the form of stone figurines, button seals, vessels, palettes and amulets, depicted the animal as a force to defend life and health. They play an important magical role. ${ }^{44}$ Some flat schist cosmetics palettes that had been used for grinding eye-paint; commonly take the form of turtles and some other creatures. An exclusive one (fig.2) apparently represents two-headed turtles, showing the dark power of the turtle. It is represented with eyes inlaid in bone for greater realism.

By the beginning of the Early-dynastic period amulets in a threedimensional form of the turtle were poplar to protect the wearer from the baneful influences that the animal personified (Fischer, 1966). Bone or ivory was favoured for amulets of the late Old Kingdom and First Intermediate Period (Hackley, 2014). Women and children were buried with often tiny amulets made gold, glazed steatite, alabaster or carnelian (Pinch, 1994), which were used as magical objects for the purpose of protection for the deceased. While the amethyst turtles evidently belong to

\footnotetext{
${ }^{44}$ For more information about the magical role of the amulets, read: Borghouts, J. "Ancient Egyptian Magical Texts, Religious Texts translation series".
} 
the Middle Kingdom, when these most beautiful semi-precious stones were regularly used (Fischer, 1966). It is easy to recognize in some amulets, the absence of the eyes and that they have not been hollowed out for this purpose (Fischer, 1968).

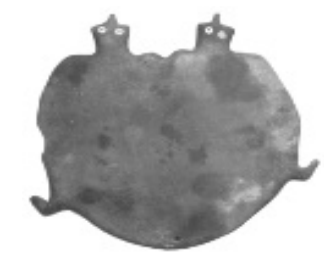

Fig.2: Predynastic cosmetic palette.

cf. Hayes, W.C. The sceptre of Egypt, vol.1, 24, fig. 17.

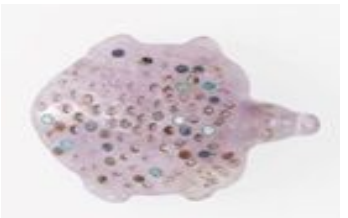

Fig.3: Turtle Amulet, Middle Kingdom. cf. Metropolitan Museum Online.

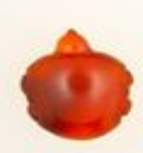

Fig.4: Turtle Amulet, New Kingdom. cf. Metropolitan Museum Online.

That damage seems to be purposefully to overthrow the animal. Among the unique amulets, is that amethyst one dating back to the $12^{\text {th }}$ Dynasty (fig.3), ${ }^{45}$ its back is covered with 108 shallow pits inlaid with turquoise, red jasper and lapis lazuli. A wide spread for the turtle amulet started again late as the New Kingdom. Some specimen is known to come from an early Eighteenth Dynasty cemetery at Sawama, near Akhmim (fig.4). More quartz and hematite amulets were found in a Theban burial of the Second Intermediate Period (Fischer, 1966).

Turtles also appeared among the various harmful creatures that have been beaten as an evil symbolize on these stelae invoking the protective power of demons. During the Later Period, magical stelae often show the demonic gods Harpocrates ${ }^{46}$ or Bes prevailing over their enemies, a procession of the well-known animals of the Middle Kingdom magical wands. They usually represent walking over a number of demons (turtles scorpions, snakes, crocodiles and lions), and sometimes represent holding some of them, on which he has power. Those demons are usually appeared surrounded by a ring to prevent their escape. Pinch, suggested that representing the god higher than those animals, and reducing the size of

${ }^{45}$ It is now in the Metropolitan Museum of Art E.26.7.1359. Arnold, D. (Spring 1995) An Egyptian Bestiary, The Metropolitan Museum of Art Bulletin, vol.3, no.4, The Metropolitan Museum of Art, New York, 34.

${ }^{46} \mathrm{He}$ is Horus as a child, son of Isis and Osiris. He is commonly represented with the index finger of the right hand on his lips, and the braided hair tuft usually placed on the right side of the head. 
negative elements (Pinch, 1994), their power was also diminished. While other writers (First, 2011), suggest that the role of those animals are as supporters and guardians.

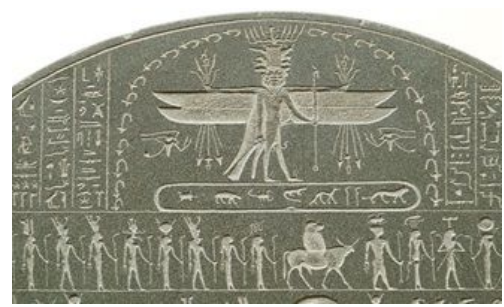

Fig.5: Metternich Stela, $3^{\text {th }}$ Dynasty.

cf. Metropolitan Museum Online.

The so called 'Metternich stela' (fig.5) which dates back to the $30^{\text {th }}$ Dynasty, ${ }^{47}$ is among those magical monuments that are filled with a numerous magical scenes, inscriptions, and protective deities; it has on the top of its reverse a scene for Bes Pantheos (represented in a polymorphic depiction with animal heads, multitude hands, bird's tail and wings) trampled a group of animals, turtle in between them. The turtle-demon represents as the last demon in the procession, the position that the animal occupied on most of the magical wands. A text part of the 'Spell for protection on water' reads: "0, you those in the water........ your mouth has been shut by the Sun (Ra), your maw has been plugged by Sekhmet, your tongue has been cut out by Thoth, your eyes have been blinded by Magic" (Allen, 2005). The whole scene is encircled by flames, the matter that shows how dangerous those demons are that require all the power of the deities to control.

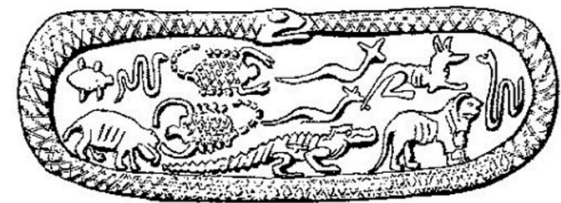

Fig.6: Magical gem

cf. West, N. Gods on small things:

Egyptian monumental iconography on

late antique magical gems and the

Greek and Demotic magical papyri, Pallas, vol.86, France, 2011, fig.18b.

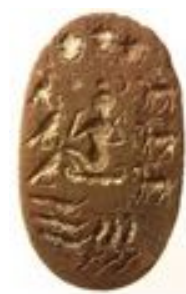

Fig.7: Magical gem

cf. Kelsey Museum of Archaeology Online, US-AAKMA_26085.

${ }^{47}$ It is in the Metropolitan Museum of Art (Fletcher Fund, 50.85). For more information see: Allen, J. P. 48-63. 
Magical gems, strictly bound with textual sources from Greek magical papyri, ${ }^{48}$ due to their obvious magical character and common technical features. They are one of the best sources to trace the iconographical of the demons during the Roman Period, which usually has a protective role. An oval shaped gem (fig.6) ${ }^{49}$ is outlined by the ouroboros serpent, depicts a precession of demons, among them and at the end of it appeared the turtledemon following a serpent. This particular gem is unusual that it omits the protective power itself (Bes or Harpocrates) control the ouroboros and the demons under their feet, as usually appeared on the gems of this period. Some writers (Cristea, 2013) mistakenly identify some of the animals performed around Harpocrates as turtles that frequently occur in the case of the stelae. But, due to the natural shape of those animals with long feet, it seems to be scarabs not turtles, as clear in (fig.7).

The main purpose of the wands was to protect the women and children of a house-hold, moreover re-appears on yet another amuletic object of the Middle Kingdom, in the form of a blue faience feeding cup (fig.8).$^{50}$ Because its design with small general size and even the tiny spout, and the procession of demons around its outer surfaces, this cup perhaps used to held milk for a baby, who receive the life-giving through the liquid. Hayes noted that the interpretation of the piece as a nursing cup ${ }^{51}$ is supported by the fact that some similar terracotta ones dating back to the same period have been found in infants burials at Thebes and Lisht (Hayes, 1953).

The scene in the cup takes place on the surrounding frieze shows a parallel procession of magical figures, all painted in black, intended to protect the child who drank from it. They are from right to left as: turtles, lions (walking, and raised up on their hind legs devouring serpents), snakes, a griffins, the goddess Taweret, and scattered among them are amuletic knifes. On the back is a figure for standing woman flanked by two figures of Bes holding serpents.

${ }^{48}$ For more information see: Brashear, W. B. The Greek Magical Papyri - an Introduction and Survey - Annotated Bibliography (1928-1994), Aufstieg und Niedergang der Römischen Welt II, band 18.5, Berlin, 1995.

49 It is in the British Museum CIB.56290. The museum has not available images for this object.

${ }^{50}$ It is found in Lisht, placed in a basket. It is now in the Metropolitan Museum of Art 44.4.4.

${ }^{51}$ More of these cups were found in Lisht, besides faience also made of stone or clay. 


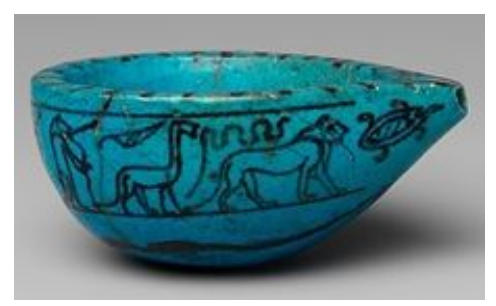

Fig.8: Feeding Cup, Late Middle Kingdom cf. Metropolitan Museum Online.

On either side of the spout, turtle occupied an extreme position as the first animal in procession and the closest to the baby's mouth. Both are represented not within the two lines that contain demons, but float outside of them. That identified it with the dark powers because of its hidden existence under the waters, and shows how much this animal is unsafe, and out of control.

The carapaces of both the two turtles have the same design. The interior detail of the carapace is reduced to three diagonal lines, and the individual border of the pattern is overstated (Fischer, 1968). It completely different from the crossed-network carapace of the turtles which decorated the majority of the wands. It also has rear rounded feet so close to those of the turtle on wand (no.10).

The role that turtle plays as a symbol of dark power because it's hidden under the water is so clear in this cup. Altenmüller suggests that the turtle as an enemy of the sun god, which swallows the Nile water during the night journey of the solar barque (Altenmüller, 2012), it responsible for the River drought which is necessary for unhindered passage and thus being born again, is paralleled to the lack of breast milk, which can only be stopped by letting the child drink from the cup, like the turtle swallowing out the Nile water.

In Ancient Egypt, as the pregnant woman her condition grew worse, the superstitious fears of the demon grew. It was even hinted that an offering had been made to the gods at the nearby temple. Nevertheless, the demon arrived to wrack some of their bodies with convulsions. They knew that a pregnant woman, possessed by a demon, might not live through the night (Harer, 2002-03). They believed that demons were the main cause for both the woman and her baby's death or for some of the giving birth responses like fever. So they have to exorcising demons using some magical tools like wands for protection against those creatures, until they were obviously relieved that the demon was quieted. 
Among those kinds of magical objects, is a painted birth-brick (fig.9) ${ }^{52}$ dating back to the $13^{\text {th }}$ Dynasty, found at Abydos. It decorated by the creatures found usually on the wands, such as lions, baboons, snakes, cat, coiled copra, and group of deities (some of them Leonine), they all march around the narrow edges of the brick. On the preserved broad face, a scene represented a seated woman holds a baby, flanked by a pair of assistants midwives (one woman poised to catch the infant, while the other provide support the mother from behind). The whole scene is bordered by two wooden Hathor-headed columns. The scene on the right upper part of side $\mathrm{E}$ is badly destroyed. Its defining feature is a body partially covered by a net-pattern. Based on comparison to figures on the magical wands, Wegner (Wegner, 2009) gave two possibilities, one of them that belong to a turtle according to such a net-pattern. It is again occupied by a place between the procession of demons.

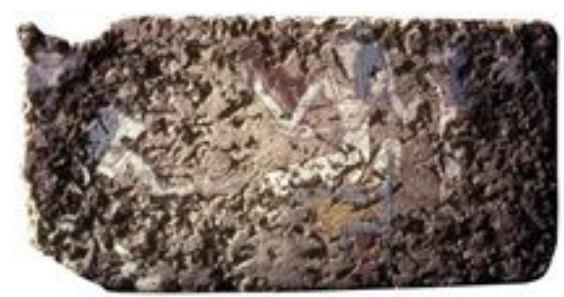

Fig.9: A mud-clay birthing brick from Abydos

cf. Wegner, J. " A Decorated Birth-Brick from South Abydos: New

Evidence on Childbirth and Birth Magic in the Middle Kingdom," fig.3.

Seemingly related to the ivory wands of the Middle Kingdom, turtledemons also appeared on some of the magical rods. The most famous and in good condition of them, is one dating back to the late Middle Kingdom (fig.10).$^{53}$ It consists of three separate hollow segments form one glazed steatite rod, and seven individual figures of animals attached by means of pins that fit holes on the undersides of the animals and in the base. Other rods have the animals facing toward the center (Arnold, 1995). On the top, the centre is busy with a single turtle flanked by two frogs, two crocodiles, and two lions on the edges. The sides of the rod are decorated by figures of more demons separated by reed mat, which Robins (Robins, 1997), considered as boundaries of the segments. The central segment is decorated on one side by figures of a lion, a cat and a crocodile, while the other side is decorated by figures, both a crocodile and a panther. The latter a preceded by in one instance, both decorated by a group of a Wedjat-eye,

\footnotetext{
${ }^{52}$ It is now in the Penn Museum E 26914.

${ }^{53}$ Found in Heliopolis, and it is now in the Metropolitan Museum of Art 26.7.1275.
} 
a protective-flame and a baboon. Each end of the rod is carved with the face of a leopard.

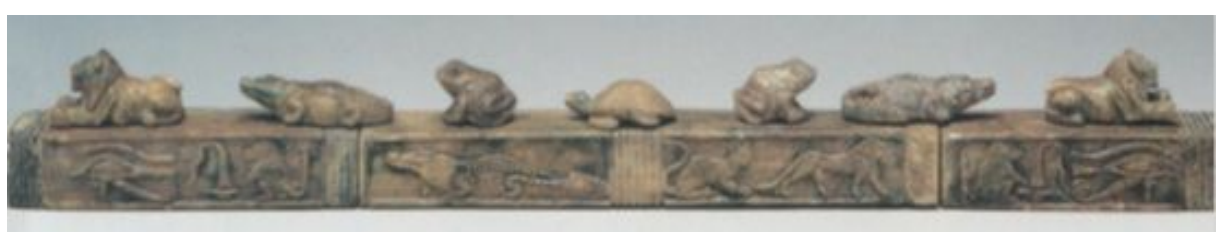

Fig.10: Magical Rod, Late Middle Kingdom cf. Metropolitan Museum Online.

Unfortunately, most of the surviving rods of this type have lost all their attached figures. A hollow segment from another magical rod (fig. 11$)^{54}$ has a turtle shown between two frogs. Another partly damaged rod (fig. 12) $)^{55}$ shows a turtle on the top, and again like the other rods, the side of the segment decorated on one side by reliefs of a lion, and a panther.

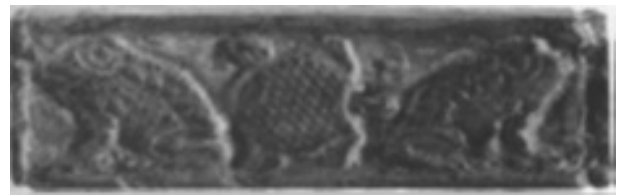

Fig.11: Fragment of a Magical Rod cf. Pinch, G. Magic in Ancient Egypt, fig.39.

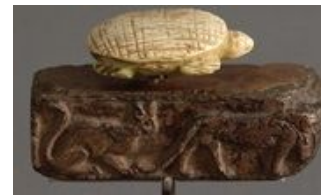

Fig.12: Fragment of a Magical

Rod

cf. Louvre Museum Online.

Some amuletic jewelry dating back to the Middle Kingdom shows the same procession of creatures and symbols for instance to the wands. A gold and silver bracelet (fig.13), perhaps designed to be placed around a child's neck, is decorated with many demons (snakes, hares, baboons, hawks, goddess Bat, two finger amulets, and at the head of the procession is a turtle). The unique thing in this piece is the religious motifs ( $D d$, anx, and $w A D t$ ) which are separated between the demons. The turtle here performed with a long neck, encircled by a serpent.

According to all these monuments, as on many Middle Kingdom magical objects that show the turtle in a convoy of demons, turtle as a demon spread around through the later periods, sometimes lead the procession, get in the center, or even get by the end of it. The figurine of the turtle appeared in consequently traditional way, its carapace covered with crossed network of lines. All these magical tools were working together during this period for the main purposes, to protect both mother

\footnotetext{
${ }^{54}$ It is now in the British Museum E 22892.

${ }^{55}$ It is now in the Louvre Museum E 26914.
} 
and children, as birth objects used by individual women, and as tools used by magicians themselves.

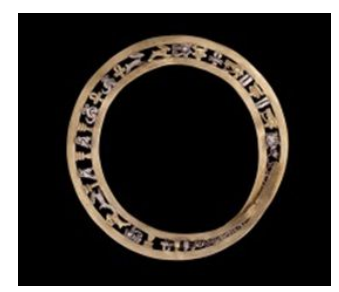

Fig.13: Gold and Silver Bracelet

cf. British Museum Press Online.

\section{TURTLE-GUARDIAN (FROM DEMON TO DEITY)}

In this section of this article, the discussion will point to another face belonging to that mysterious animal. By the end of the Second Intermediate Period, a new generation of the turtle-demon appeared and served starting from the $18^{\text {th }}$ Dynasty, fighters in the form of turtle-headed human guardians protect the deceased. In general, we can document two different kinds of Demons: Wandering (Malevolent) Demons and Guardians (Benevolent) Demons. The first class usually sends by different deities and sometimes on their own consensus to bring diseases, misfortune or nightmares for certain human being. While the second class are the guardians of certain places (Earth or Underworld) against that kind of involvement and infection. Both the two groups were distinct from the Egyptian worldview.

That role and importance of the guardians as demonic creatures changed completely during the Late and Greco Roman Period, in sources dating to that period, we notice an increased tendency to interpret daily life accidents and misfortune as resulting from demonic influence (Lucarelli, 2010). They came to be regarded as deities like, for example, god Tutu (Great of Strength) aA pHty, the first of the Seven Demons who was particularly worshipped in the Greco-Roman Period with his own temple cults. His name was also transliterated in Greek as Apathes and used as personal name (Lucarelli, 2011).

The guardians are part of the massive legion of the dwellers of the Underworld, where the sun god descended during his journey in order to unite with the deceased body of Osiris (Lucarelli, 2011). They watch over gates, portals and doors which are described in the spells nos.144-147 of the Book of the Dead, and can be found in the Coffin Texts (Barguet. 1967). Their importance is not only to guard the gates but also to protect the deceased who must be ready not only to know their names, but also to 
recognize them (Lucarelli, 2006). They are taking part in that type of magical procession of those creatures and animals who intended to turn away evil. Such alignments are known from different objects, mostly from coffins, temples and tombs. They are shown with human bodies, and heads of animals, birds, reptiles or insects. Some have two heads, or a head that faces backwards (Pinch, 1994). No explanation can be given for the phenomena that this guardian sometimes represented as a female figure and other as a male.

Turtle-headed guardians are among those creatures that are relatively uncommon and rare in the Ancient Egyptian iconography. They appeared mostly in the funerary domain where they attend as protectors. Those guardians are named with epithets that usually refer to some fear exciting detail of their image, and their appearances are typical of demonic beings. They are titled in the texts as $n T r$ 'god', but Lucarelli believed that they are 'demons' not deities namely supernatural beings which arbitrate between gods and mankind (Lucarelli, 2010). Although, the $n T r$ determinative can title the dwellers of the netherworld and in particular the guardians.

Turtle was considered malevolent but whose power could be used for protection. As many other guardians, Turtle-headed guardian the guard of the Third Gate of the Book of the Dead has a double name, one referring to a physical feature and the other to moral behaviour. It is named wnmHwAAt 'One who eats the excrement, ${ }^{56}$ which appeared in spell 144 on many monuments. A comparison of its names in the spell, as taking place in a Greco-Roman period Papyrus Turin 1791 (Lepsius, 1842), where the name reads as wnm HwA.w $n(t)$ pHwy.f, 'One who eats the excrement of his rectum'; while on the second western Osirian chapel in the temple of Dendera (Cauville, 1997), it reads regularly as only wnm-HwAAt. It appeared with the same name on many other sarcophagi, tombs and papyri of different periods, like for example tomb of Ramsses III (Hornung, 2013) which dating back to the $19^{\text {th }}$ Dynasty, Papyrus of Nesipaheran (Blackmann, 1918 \& Guilhou, 2009) which dating back to the $21^{\text {st }}$ Dynasty.

Some of the demons or the guardians; names describe their physical form, which is the most recognizable aspect of the demon itself. Among them are two names indicating that the guardian who has turtle face, $\mathrm{ST} w-\mathrm{Hr}$ 'Turtle-face' and $S T w y-H r$ 'The two turtle-faced ones'. But Faulkner read both the two names which appeared in the Spells 1043 and 1155 of the Coffin Texts as: "He whose face is covered" (Faulkner, 1977). Both, are connected directly to the poplar name of the animal itself Stw, reflect both

${ }^{56}$ For more information see: Pantalacci, L. (1983). Wnm-HwAAt: Genèse et carrière d'un génie funéraire," BIFAO, tome 83, Institut français d'archéologie orientale, Le Caire, 297-311. 
animal characteristics and physical attributes at the same time, and display its nature as inhabit the foggy waters of the Underworld.

In the Late Period coffins, turtle headed creatures can be seen on some different coffins dating to the times of $21^{\text {st }}$ till $26^{\text {th }}$ Dynasties; with the same traditional figure but in different titles. The main purpose of this turtle-guardian is to protect the body of the deceased. It appeared on the outer red granite sarcophagus of King Merenptah (1 $9^{\text {th }}$ Dynasty) which was reused by King Psusennes I (21 ${ }^{\text {st }}$ Dynasty) (fig. 14); ${ }^{57}$ in this case the name of the guardian is omitted. On it the guardian is represented sitting on the ground and holding a knife by the right hand on the knee, while the left fist rest on the chest. We have to record also that the same sarcophagus contains two more turtles as a part of the zodiac that surrounds the body of goddess Nut on the lid of the sarcophagus, it is the 0 "Stwy Decan.

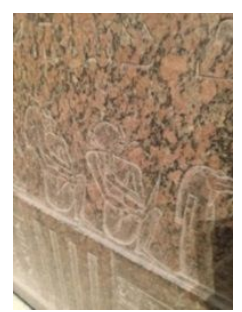

Fig.14: Sarcophagus of King Merenptah which reused by King Psusennes

cf. Egyptian Museum, on the site.

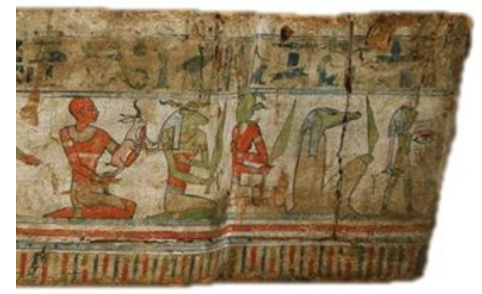

Fig.16: Coffin of Horaawesheb cf. British Museum, On Line.

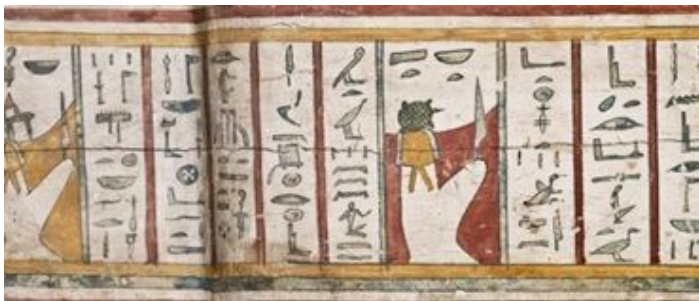

Fig.15: Coffin of Isisirdis cf. Swedish National Museum. Photograph number 15421D, Copyright (C)2017 Medelhavsmuseet.

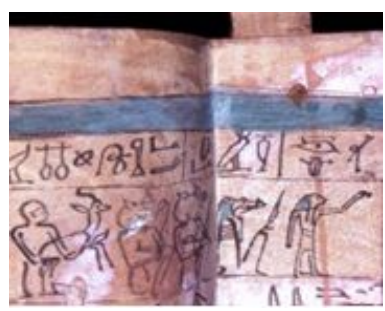

Fig.17: Coffin of Ankhefenkhons cf. British Museum, On Line.

${ }^{57}$ It is found in Tanis, and now in Cairo Museum (JE 6337B). For more information see: Montet, P. (1951). La nécropole royale de Tanis, vol. 2: Les constructions et le tombeau de Psousennès à Tanis, Jourde et Allard, Paris, 11920 . 
Other examples of picturing the turtle-guardians on non-royal coffins are considering a further evidence of the exclusive of funerary beliefs and practices during this period. On the outer anthropoid coffin of Isisirdis (fig.15), ${ }^{58}$ very similar dressed different headed fantastic creatures per side surrounded by columns of text appeared on the outer surfaces. Those underworld deities are dressed in white shrouds, yellow necklaces and blue wigs; and holding knives on their knees. The turtle-headed guardian represented in profile as usual; and named $\square$ - nbt $S t$ "Lady of the Lake." Because of the nature of the turtle as a water-dwelling animal, both name and iconography refer to aquatic areas of the Underworld.

The epithet $n b t S t$ which connected to the lake was usually used originally for Hathor, Lady of the Red Lake (Leitz, 2002) and for Sobek, Lord of the Lake (Leitz, 2002). Only for a single time on the Coffin of Nefer-Renept,

Goddess Nut named as nbt Styw "Lady of the turtle" (Andelkovic, 2015). The trough of Nefer-renepet's coffin carries a figure of Nut recognized by the large maat plume upon her head and stands upon a tall perch. The name is a part of a profile line drawing in yellow pigment surrounding the body of Nut (Andelkovic, 2015). According to Helck, one of the epithets of goddess Sekhmet is 0 DID Stw 'Lady of the turtle' (Helck, 1961), it performed in a rare confusing form with the carapace in profile ( $\sqrt{ }$ IJ $)$ with two pairs of very human legs' (Fischer, 1968 \& Brunton, 1927). That epithet shows the great relation between the turtle as a guardian and both the goddess Hathor, Nut and Sekhmet.

Two more coffins dating back to the 22th Dynasty, now in the British Museum, their outer surfaces also decorated by the identical guardians' procession are found on the sarcophagus King Psusennes. On the Coffin of Horaawesheb (fig.16), ${ }^{59}$ the incense-bearer in the temple of the god Khonsu at Thebes, the reddish-brown skin guardian is represented sitting on the ground and holding a knife by the right hand on knee, while the left fist rest on the chest, wearing a yellow necklaces and short skirt. The other Coffin of Ankhefenkhons (fig.17), ${ }^{60}$ on it the turtle-guardian rarely represented twice, in the form of two turtle-headed deities siting side beside sitting on the ground and each holding a knife by the right hand on knee, while the left fist rest on the chest, without any certain closes are

\footnotetext{
${ }^{58}$ It is Coffin no.0004 in the Swedish National Museum at Stockholm, dated back to the Late Period.

${ }^{59}$ Coffin of Horaawesheb, it is now in the British Museum EA6666.

${ }^{60}$ Coffin of Ankhefenkhons, it is now in the British Museum EA30721. It seems that the coffin is unfinished.
} 
clear. It is clear that this guardian always occupies a place near the left shoulder of the deceased near the head, which matter that refer to its importance.

Another very rare find-type is the turtle-headed guardians' statues. The name and function of these statues found in the tombs of Horemheb (KV 57) (fig. 18) ${ }^{61}$ and Ramsses I (KV 16) (fig.19), ${ }^{62}$ are not known but it. They are among the mythical forms of the demons or the guardians who were created to protect the king in his journey in the Underworld and in his travels with the Sun god Ra. Those two statues are not the only of these kinds of guardians, other similar magical statuettes ${ }^{63}$ found in the tomb of Tutankhamun, but with the different headed animals.

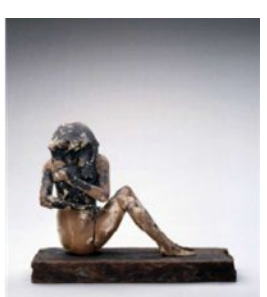

Fig.18: Turtle-headed guardians' statue - tomb of Horemheb (KV 57) cf. British Museum, On Line.

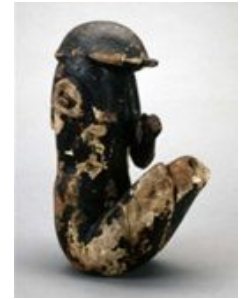

Fig.19: Turtle-headed guardians' statue - tomb of Ramsses I (KV 16) cf. British Museum, On Line.

These well carved sycamore wood statues, are represent a human figure sitting on the ground; the first statue which is found overlain with plastered linen is represented with its lower half in profile and upper body turned to the side, while the second which is covered in black resin is represented completely in profile. Each one over has a large turtle displayed without legs and with the head out, possibly this is to make the image more familiar as the animal itself. We can easily recognize that the artist chose to represent the turtle here in vertical position close to its nature, not in profile like its figurine in most of the scenes. A divine wig has been used to mask the pass between animal and human. However, it is unclear whether the wig passes over or under the turtle's shell (Russmann, 2001).

${ }^{61}$ It is in the British Museum EA50704. For more information see: Russmann, E. R. (2001). Eternal Egypt- Masterworks of Ancient Art from British Museum, University of California Press, New York, 160f.

${ }^{62}$ It is in the British Museum EA61416. For more information, read: Reeves. N. \& Wilkinson, R. H. (1996). The Complete Valley of the Kings - Tombs and treasures of Egypt's Great Pharaohs, Thames \& Hudson Ltd, London, 134-5.

${ }^{63}$ For more information about these kind of statues, see: Fischer, H. G. "The Ancient Egyptian Attitude towards the Monsters," 13-26. 


\section{DECANS AND DEMONS}

Some authors believed that there is a connection between decans ${ }^{64}$ and demons, which they considered genies (Antoniadi, 1934). For example, Kaper suggested that this correlation between decans and demons which are under the command of Sekhmet, with whom the decans share a similar role (Kaper, 1995). Both decans and demons may cause death and disaster upon earth, and both groups are found represented upon some astronomical ceiling of Esna and Dendera Temples.

The name of the Decan Stwy (Hannig, 1999 \& Gadré, 2008). used to identify turtle-demon at the same time, the name describes the physical form of the turtle, which is the most recognizable aspect of the demon itself. Both, are connected directly to the poplar name of the animal itself Stw, displays its nature as inhabit the foggy waters. We could recognize that both turtle-guardian and turtle-decan occupy the same important spot on the coffins and their lids, around the head of the deceased, specially his left shoulder. On four coffins (Kleopatra, Seonsaos, Heter \& Petemenophis) dated back to the Greco-Roman Period, a special spot around the head of the goddess Nut chosen to be occupied by the turtledecan Stwy not any other decans, placed in the direct vicinity of her arms. On Heter coffin (fig.20), ${ }^{65}$ the two turtles appeared to the right of Nut's head, the place which versus the left shoulder of the deceased himself. The pair of turtles is followed by a seated crocodile-headed dog holding two knives, which seems to be a kind of demon-guardian.

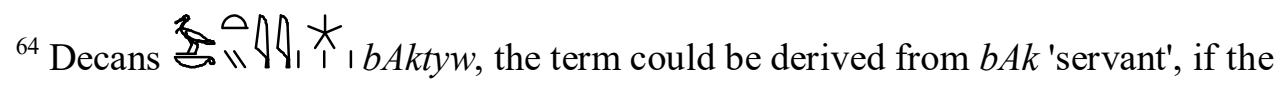
stars were seen as servants of the sun and moon. They are thirty-six stars formed the southern group belt, constellations, or subdivisions of constellations, rising at particular hours of night. Each one is rising heliacally for 10 days apart and invisible for 70 days. For more information see: Neugebauer, O. \& Parker, R. A. (1969). Egyptians Astronomical texts III: Decans, Planets, Constellations and Zodiacs, Brown University Press, London; Toomer, G. J. (1972). "Mathematics and Astronomy," The legacy of Egypt, Oxford University Press, Oxford, 46; Relek, J. \& Ernest A. (2003). "Ancient Egyptian Astronomy: Ursa Major- Symbol of Rejuvenation," Archaeoastronomy, vol.17, Austin, 67.

${ }^{65}$ It is the wooden coffin of Heter probably from Thebes but now lost. It dated back to about 125 A.D. For more information see: Neugebauer, O. \& Parker, R. A. vol.3, 93. 


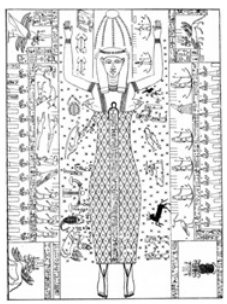

\section{Fig.20: Coffin lid of Heter}

cf. Neugebauer, O. \& Parker, R. A. Egyptians Astronomical texts, vol. 3, p1.50.

As I mentioned before, on the four coffins (Psusennes, Isisirdis, Horaawesheb \& Ankhefenkhons) (figs.14 to 17) dated back to the Late Period, turtle-guardians always occupy a place near the left shoulder of the deceased. That position of both kinds of turtles (guardians and decans) on the lids and outer surfaces of the coffins, also the position of the head of the goddess Nut over the head of the deceased ${ }^{66}$ in those coffins, show the symbolically relations between them and the importance of this animal in the otherlife.

\section{Conclusion}

On the basis of the evidence currently available, it seems fair to suggest that turtles occupy a clear important place within the Ancient Egyptian demonology. This article explores the range and variation of the ambiguity turtle. The Ancient Egyptians believed it was capable of harm and help. While previous demonological articles focused on issues related to definitions, the writer discussed the appearances of turtle-demons through iconography, or object, or textual description. For the sake of discussion, I contend with the difference between the turtle- demon and turtle-guardian, which is not as clear-cut as popular views might suggest. I also provide strong convincing evidence that there was a great relationship between the turtle as a demon and a decan.

This article is based on a set of fifteen wands from various museum collections. Some of the wands found in tombs may have been specially made to protect the deceased, and to be used to defend himself against demons using the large number of the creatures among them are turtles.

${ }^{66}$ She ready to enfold and hug the deceased in a sexually charged union that donated to the process of resurrection. She is oriented west with the southern and northern constellations positioned accordingly. 
This procession of demons is held mythological responsible for stranding the Solar-barque in the Nile River.

During the Late and Greco-Roman periods we begin to note an enlarging of some apotropaic gods whose special mission is to control the aggressive powers of demons. They also direct them to the proper target. Turtle is comprised of those guardians who keep watch over the deceased on the coffins, or even in the form of statues of turtle-headed guardians. However, it seems that her nature can be different than the usual guardian demons as she does not appear in spells connected to the protection of the Underworld gates.

\section{REFERENCES}

- Allen, J. P. (2005). The Art of Medicine in Ancient Egypt, Metropolitan Museum of Art, New York, 29.

- Allen, T. G. (1974). The Book of the Dead or Going Forth by Day-Ideas of the Ancient Egyptians Concerning the Hereafter as Expressed in their Own Terms, Studies in Ancient Oriental Civilization, vol. 37, University of Chicago Press., Chicago, 712.

- Altenmüller, H. (1965). Die Apotropaia und die Götter Mittelägyptens: Eine Typologishe und Religionsgeschichichtliche Untersuchung der Sogenannten 'Zaubermesser' des Mittleren Reichs, Ludwig-Maximilians-Universität, München, 7-8, $31 \& 57-63$.

- Altenmüller, H. (2012). "Die Schildkröte in Ritual und Magie des Alten Ägypten", Auf den Spuren des Sobek: Festschrift für Horst Beinlich zum, band 28, Dettelbach, 15-29.

- Andelkovic, B. \& Elias, J. P. (2015). "Inscriptions on the Interior of the 30th Dynasty Coffin of Nefer-renepet from Akhmim," Ethnology and Anthropology, no.10m, issue 3, Belgrade, 709 \& 712.

- Antoniadi, E.M. (1934). L'astronomie Ègyptienne- depuis les temps les plus reculés jusqu'a la fin de l'époque Alexandrine, Gauthier-Villars, Paris, 77.

- Arnold, D. (Spring 1995). An Egyptian Bestiary, The Metropolitan Museum of Art Bulletin, vol.3, no.4, The Metropolitan Museum of Art, New York, 34-35.

- Barguet, P. (1967). Le livre des morts des anciens égyptiens, Littératures anciennes du Proche Orient, tome 1, Paris, 190.

- Bates, O. (1917). Ancient Egyptian Fishing, Harvard African Studies, vol.i, African Department of the Peabody Museum of Harvard University, Cambridge, 210.

- Becker, U. (1994). The Continuum Encyclopedia of Symbols, Continum, London, 310-11.

- Blackmann, A. M. (1918). "The funerary papyrus of Nespehera-an», JEA, vol.5, Egypt Exploration Society, 24-35.

- Borghouts, J. F. (1978). Ancient Egyptian Magical Texts, NISABA: Religious Texts Translation Series, Leiden. 
- Borghouts, J. F. (1973). "The Evil Eye of Apopis Source," JEA, vol. 59, Egypt Exploration Society, London, 137.

- Brashear, W. B. (1995). The Greek Magical Papyri - an Introduction and Survey - Annotated Bibliography (1928-1994), Aufstieg und Niedergang der Römischen Welt II, band 18.5, Berlin,

- Brunton, G. \& Engelbach, R. (1927). Gurob, British School of Archaeology in Egypt, London, pl.32.

- Carr, A. F. (1952). Handbook of Turtles, Cornell University Press, New York, 428.

- Cauville, S. (2001). Dendera - Le fonds hiéroglyphique au temps de Cléopâtre, Paris, I2.

- Cauville, S. (1997). Le temple de Dendara: Les chapelles osiriennes, 3 vols., BdE, tome 117-119, Cairo, pl.193.

- Christoph, S. \& Willi, S. (2008). "The Egyptian Tortoise, Testudo kleinmanni Lortet, 1883 in Libya," Salamandra - German Journal of Herpetology, vol.44, no.3, Berlin, 141-152.

- Cirlot, J. E. (2002). A Dictionary of Symbols, translated by Sage, J., Courier Dover Publications, London, 353.

- Cristea, S. (2013). "Egyptian Greek Roman Harpocrates A Protecting and Saviour God," Moga, Angels, Demons and representations of afterlife, Editura Universităţii "Alexandru Ioan Cuza, Romania, 78.

- De Buck, A. (1961). The Egyptian Coffin Texts, The University of Chicago Press, Chicago, 30, spell 368.

- Delvaux, L. (2014). "Grenouilles et crocodiles: Objets et pratiques magiques dans l'Egypte du Moyen Empire," Bulletin de l'Académie royale des Sciences d'Outre-Mer, tome 60 (3-4), Belgium, 403.

- Erman, A. \& Grapow, H. (1962). Wörterbuch der Aegyptishen Sprache, 5 vols, Hinrichs' sche Buchhandlung, Leipzing,

- Faulkner, R. O. (1981). A concise dictionary of Middle Egyptian, Griffith Institute - Ashmolean Museum, Oxford,

- Faulkner, R. O. (1933). Papyrus Bremner-Rhind (British Museum no.10188), Bibliotheca Aegyptaca III, Bruxelles, 90 (32, 26).

- Faulkner, R. O. (1977). The Ancient Egyptian Coffin Texts, Aris and Phillips, Warminster, spell 310, vol.1, 228, no.2 \& vol.3, 135.

- First, G. (2011). "Polymorphic or pantheistic deities? - Some Problems with Identification and Interpretation. Contribution to the Manifestation of God in Late Egyptian Religion and Magic," Studies on ReligionSeeking Origins and Manifestations of Religion, Acta Archaeologica Pultuskiensia vol.3, Pułtusk, 63.

- Fischer, H. G. (1968). Ancient Egyptian representation of turtles, The Metroploitan Museum of Art Papers, Papers o.13, New York,

- Fischer, H. G. (1966). "Egyptian Turtles," Bulletin of The Metropolitan Museum of Art, vol.24, New York, 193-200. 
- Fischer, H. G. (1987). "The Ancient Egyptian Attitude towards the Monsters," Monsters and Demons in the Ancient and Medieval Worlds - papers presented in Honor of Edith Porada, Philipp von Zabern, Mainz, 15.

- Gadré, K. (2008). Conception d'un modèle de visibilité d'étoile nu, Application ä l'identification des décans égyptiens, Université de Toulouse, Toulouse, table $1 \& 257$.

- Gardiner, A. H. (1944). Hieratic Papyri in the British Museum, London, $121, \mathrm{p} 1.68$.

- Guilhou, N. (26 June 2009). "Lézards et geckos dans l'Égypte ancienne," IVe Rencontres archéozoologiques de Lattes, UMR 5140 - CNRS, Université PaulValéry Montpellier 3, 8.

- Gutbub, A. (1979). "La tortue - animal cosmique bénéfique à l'époque ptolémaique et romaine," Hommages à la mémoire de Serge Sauneron, vol. I: Egypte pharaonique, Bibliothèque d' Etude 81, Le Caire, 405.

- Hackley, L.D. (2014). Amethyst, Apotropaia and the Eye of Re, Master deg. Thesis, The American University in Cairo, School of Humanities and Social Sciences, Cairo, 6-8, $69 \& 86$.

- Hannig, R. \& Vomberg, P. (1999). Wortschatz der Pharaonen in Sachgruppen, Verlag Philipp von Zabern, Mainz, 197.

- Harer, W. B. (2002-03). An Exercise in Exorcism, Egyptian Style - Modern Medicine Expels an Ancient Demon, Ostracon, vol.14, no.1, 3.

- Hayes, W. C. (1953). The sceptre of Egypt: vol.1, A background for the study of the Egyptian Antiquity in the Metropolitan Museum of Art from the earliest time to the end of the Middle Kingdom, Plantin Press, New York, 247.

- Helck, W. (1961). Urkunden des ägyptischen Alterums, Akademie - Verlag, Berlin, band 4, 1766.9.

- Hornung, E. (2013). "Ägyptens göttliche Mischwesen," in Spinnenfuss Und Krotenbauch: Genese Und Symbolik Von Kompositwesen, Theologischer Verlag, Zürich, 3 \& fig. 2.

- Hornung, E. (1956). "Chaotische bereiche in der geordneten Welt," ZÄS, band 81, Berlin, 32.

- Kanawati, N. \& Woods, A. (2010). Beni Hassan, Art and Daily Life in an Egyptian Province, Cairo, 79.

- Kaper, O. E. (1995). "The astronomical ceiling of Deir el-Haggar in the Dakhleh Oasis," JEA, vol.81, Egypt Exploration Society, London, 182-3.

- Kitchen, K. A. (1993). Ramesside Inscriptions Translated and Annotated, Chichester: Wiley-Blackwell, Oxford, 58.

- Koenig, Y. (2004). "The image of foreigner in the magical texts", in: Kousoulis, P.I.M. \& Magliveras K. (eds.), Moving across borders: foreign relations, religion and cultural interactions in the ancient Mediterranean, Orientalia Lovaniensia Analecta, 235.

- Leeman, D. (2019). Apotropaic Wands of the Middle Kingdom, Australia, 6.

- Legge, F. (1905). "The Magic ivories of the Middle Empire." PSBA, vol.xxvi, London, pl.16, fig. 40 . 
- Legge, F. (1906). "The Magic ivories of the Middle Kingdom, part ii" PSBA, vol.xxvii, London, 151.

- Leitz, Ch. (2002). Lexikon der ägyptischen Götter und Götterbezeichnung, Peeters, Leuven, vol.4, 139 \& vol.3, 745.

- Lepsius, R. (1842). Das Todtenbuch der Ägypter nach dem hieroglyphischen Papyrus in Turin, Leipzig, pl.lx.

- Lesko, L. H. (2004). A Dictionary of Late Egyptian, second edition, Brown University, USA.

- Lesko, L. H. (1972). The Ancient Egyptian Book of Two Ways, University of California Publications. Near Eastern Studies, vol.17, Berkeley, 77-92.

- Loud, G. (1952). Mefiddo - seasons of 1935-39, vol.2, University of Chicago, Oriental Institute Publication, vol.62, Cambridge University Press, London, pl.203.

- Loveridge, A. \& Williams E. E. (1957). Revision of the African tortoises and turtles of the suborder Cryptodira, Bulletin of the Museum of Comparative Zoology, vol.115, no.6, The Museum of Comparative Zoology, London, 163-557.

- Lucarelli, R. (2010). "Demon (Benevolent and Malevolent)," UCLAEncyclopedia of Egyptology, vol.1249, version 1, La Collezione Egiziana: Museo Civico Archeologico di Bologna, Milano, 7.

- Lucarelli, R. (2011). "Demenology during the Late Pharaonic and GrecoRoman Periods in Egypt,: Journal of the Ancient Near Eastern Religions, vol.11, New York, 115-118 \& 123.

- Lucarelli, R. (2009). "Popular Beliefs in Demons in the Libyan Period: The Evidence of the Oracular Amuletic Decrees," The Libyan Period in Egypt, Historical and Cultural Studies into the $21^{\text {th }}-24^{\text {th }}$ Dynasties: Proceedings of a Conference at Leiden University at 25-27 October 2007, Peerers, Leuven, 236.

- Lucarelli, R. (2006). The Book of the Dead of Gatseshen: Ancient Egyptian funerary religion in the 10th century BC., Egyptologische Uitgaven, band 21, Leiden, 95-104.

- Lucarelli, R. (2010). "The Guardian - demons of the Book of the Dead," BMSAES, vol.15, British Museum online press, http://www. britishmuseum. org/ research/online_journals /bmsaes / issue_15/ lucarelli.aspx. (Accessed on 6 Apri 2020), 86.

- Meeks, D. (2001). "Demons," The Oxford Encyclopaedia of Ancient Egypt, vol.1, Oxford, 375-377.

- Miniaci, G. (2020). The Middle Kingdom Ramesseum Papyri Tomb and its Archaeological Context, (Kitab - Egyptology in Focus, Book 1), Material Culture of ancient Egypt and Nubia, London, 106, pl.xv.h.

- Miniaci, G. \& Quirke, S. (2009). Reconceiving the Tomb in the Late Middle Kingdom- The Burial of the Accountant of the Main Enclosure Neferhotep at Dra Abu al-Naga," BIFAO, tome 109, Institut français d'archéologie orientale, Le Caire, 355.

- Mitchell, A. \& Simon M. S. (January 2001). "Salmonella in Reptiles Mark," Seminars in Avian and Exotic Pet Medicine, vol.10, no.1, Philadelphia, 25-35. 
- Montet, P. (1951). La nécropole royale de Tanis, vol. 2: Les constructions et le tombeau de Psousennès à Tanis, Jourde et Allard, Paris, 119-20.

- Murray, M. A. (1906). "The astrological character of the Egyptian Magical wands," PSBA, vol.xxvii, London, 297-311.

- Neugebauer, O. \& Parker, R.A. (1969). Egyptians Astronomical texts III: Decans, Planets, Constellations and Zodiacs, Brown University Press, London.

- Pantalacci, L. (1983). "Wnm-HwAAt: Genèse et carrière d'un génie funéraire," BIFAO, tome 83, Institut français d'archéologie orientale, Le Caire,

- Petrie, W. M. F. (1927). Objects of Daily use, London, 297 \& 311.

- Pinch, G. (1994). Magic in Ancient Egypt, British Museum Press, London, 1819, 34, 40-1 \& 130.

- Reeves. N. \& Wilkinson, R. H. (1996). The Complete Valley of the Kings Tombs and treasures of Egypt's Great Pharaohs, Thames \& Hudson Ltd, London, 134-5.

- Relek, J. \& Ernest A. (2003). "Ancient Egyptian Astronomy: Ursa MajorSymbol of Rejuvenation," Archaeoastronomy, vol.17, Austin, 67.

- Rittner, D. \& McCabe, T. L. (2004). Encyclopedia of Biology, Facts on File: Library of World History, New York, 290.

- Roberson, J. (2009). "The Early History of New Kingdom Netherworld Iconography: A Late Middle Kingdom Apotropaic Wand Reconsidered," Archaism and Innovation: Studies in the Culture of Middle Kingdom Egypt, Philadelphia: Department of Near Eastern Languages and Civilizations; University of Pennsylvania Museum of Archaeology and Anthropology, New Haven, 436.

- Robins, G. (1997). The Art of Ancient Egypt, London, 115.

- Russmann, E. R. (2001). Eternal Egypt- Masterworks of Ancient Art from British Museum, University of California Press, New York, 160f.

- Säve-Söderbergh, T. (1956). "Eine ramessidische Darstellung vom Tőten der Schildkröte," Mitteilungen des Deutschen Archäologischen Institute, Abteilung Kairo, band 14, Wiesbaden, 175-180 \& fig. 1.

- Sethe, K. (1908). Die Altegyptishchen Pyramidentexte- nach den Papierabrüchen und Photographien der Berliner Museum, Leipzing, Utr.535.

- Steindorff, G. (1946). "The Magical Knives of Ancient Egypt," The Journal of the Walters Art Gallery, vol.9, Baltimore, 50.

- Szpakowska, K. (2009). "Demons in Ancient Egypt," Religion Compass, vol.3, no.5, Blackwell Publishing, Oxford, 802-03.

- Szpakowska, K. (2011). "Demons in the dark: Nightmares and other nocturnal enemies in Ancient Egypt," Ancient Egyptian Demonology - Studies on the Boundaries between the Demonic and the Divine in Egyptian Magic, Orientalia Lovaniensia Analecta, vol.175, Peeters, Leuven, 76.

- Toomer, G. J. (1972). "Mathematics and Astronomy," The legacy of Egypt, Oxford University Press, Oxford, 46.

- Vermis, P. (1990). Future at Issue. Tense, Mood and Aspect in Middle Egyptian: Studies in Syntax and Semantics, New Haven, 90, no.159. 
- Vink, F. (2016). "Boundaries of Protection. Function and significance of the framing (lines) on Middle Kingdom apotropaia, in particular magic wands, The World of Middle Kingdom Egypt (2000-1550 BC) Contributions on archaeology, art, religion, and written sources, London, 260.

- Walle, B. Van de (1953). "La tortue dans la religion et la magie égyptiennes," La nouvelle Clio, tome 5, Brüssel, 173-189.

- Wegner, J. (2009). "A Decorated Birth-Brick from South Abydos: New Evidence on Childbirth and Birth Magic in the Middle Kingdom," Archaism and Innovation: Studies in the Culture of Middle Kingdom Egypt, University of Pennsylvania Museum of Archaeology and Anthropology, New Haven, 447-496.

- Wegner, J. (2015). "The Goddess Taweret: Protector of Mothers and Children," Glencairn Museum News at Septemper 2014, Glencairn Museum online, http://www.glencairnmuseum. org/ newsletter, 29/8/2015.

- West, N. (2011). Gods on small things: Egyptian monumental iconography on late antique magical gems and the Greek and Demotic magical papyri, Pallas, vol.86, France.

\section{List of Abbreviations}

LE Lesko, L. E. (2004). A Dictionary of Late Egyptian, second edition, Brown University, USA.

ME Faulkner, R.O. (1981). A concise dictionary of Middle Egyptian, Oxford University Press, Oxford.

PL Wilson, p. (1997). A Ptolemaic Lexicon, A Lexicographical Study of the Texts in the Temple of Edfu, Leuven.

Wb Erman, A. \& Grapow, H. (1962). Wörterbuch der Aegyptishen Sprache, 5 vols, Hinrichs' sche Buchhandlung, Leipzing.

\section{Plate 1: Magical Wands}

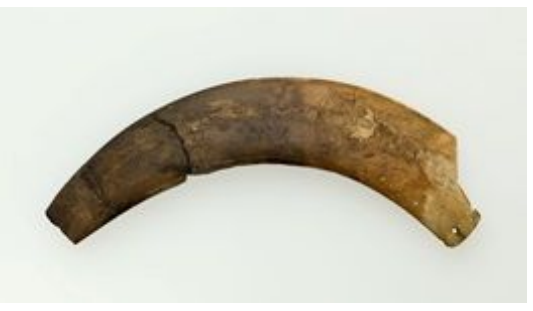

no. 1

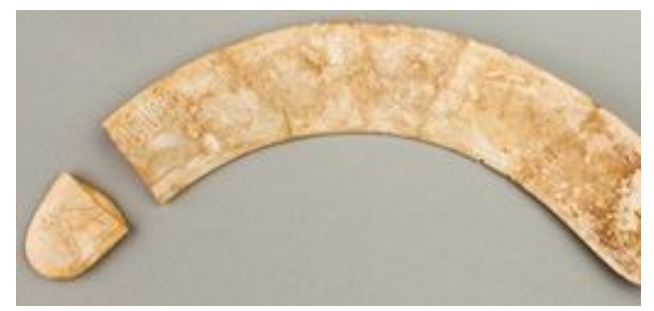

no.2. 


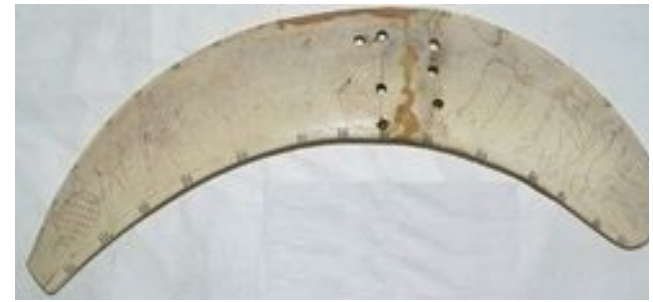

no. 3

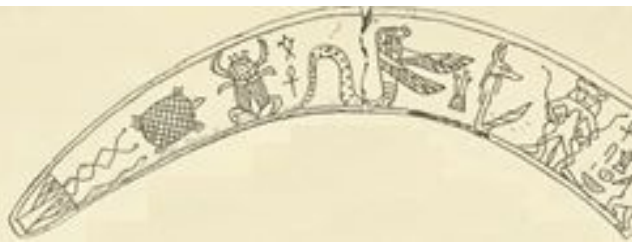

no. 5

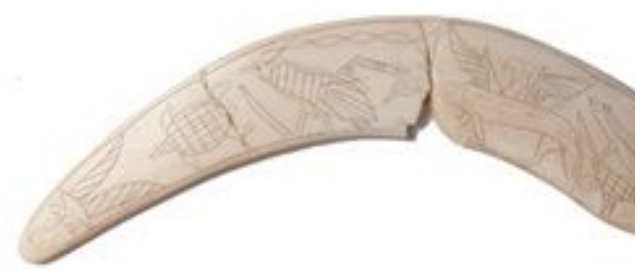

no. 7

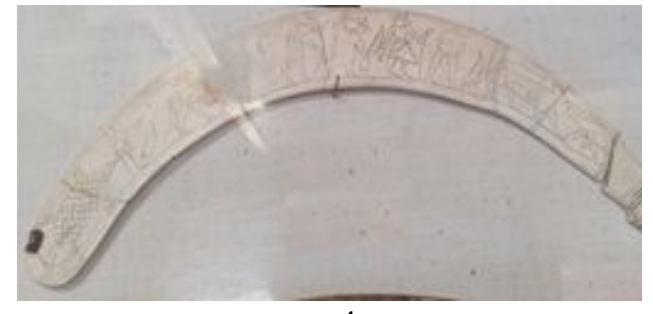

no. 4

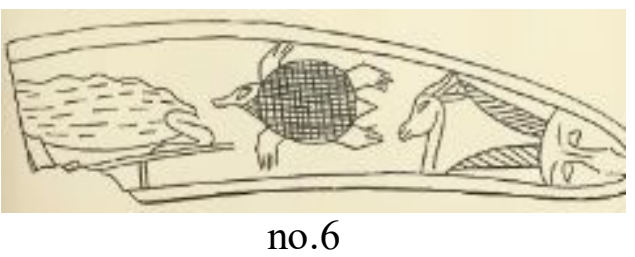

no. 6

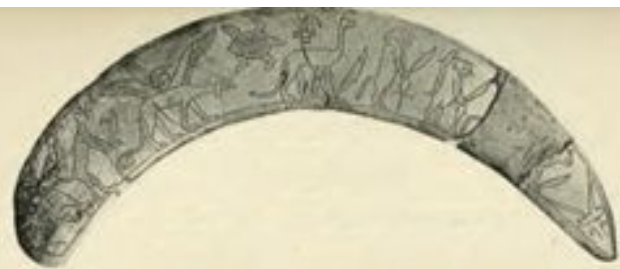

no. 8

cf. (1) Metropolitan Museum Online; (2) Metropolitan Museum Online; (3) British Museum Online; (4) Egyptian Museum onsite; (5) Legge, F. "The Magic Ivories of the Middle Kingdom," pl.9, fig.15; (6) Legge, F. "The Magic ivories of the Middle Kingdom, part ii" $P S B A$, vol.xxvii, London, 1905, pl.16, fig.40; (7) Miniaci, G. The Middle Kingdom Ramesseum Papyri Tomb and its Archaeological Context, p.106, pl.xv (H); (8) Legge, F. "The Magic ivories of the Middle Empire," p.162, pl.3, fig. 51 .

\section{Plate 2: Magical Wands}

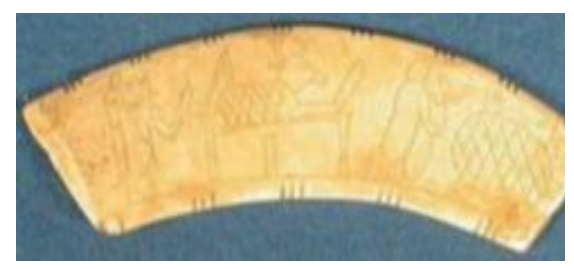

no.9

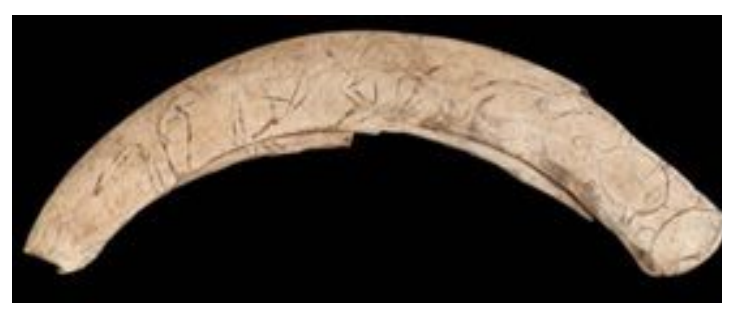

no. 10 


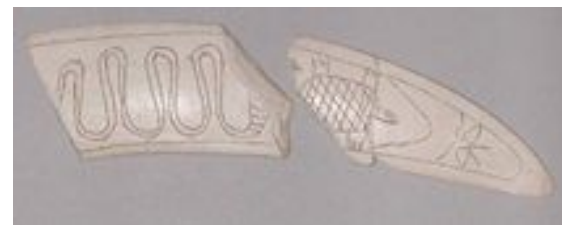

no. 11

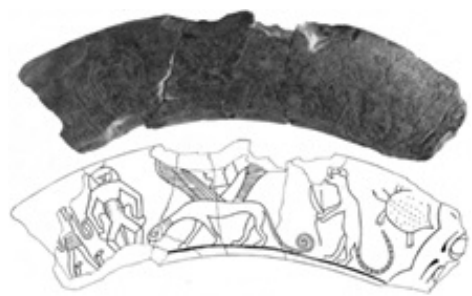

no. 13

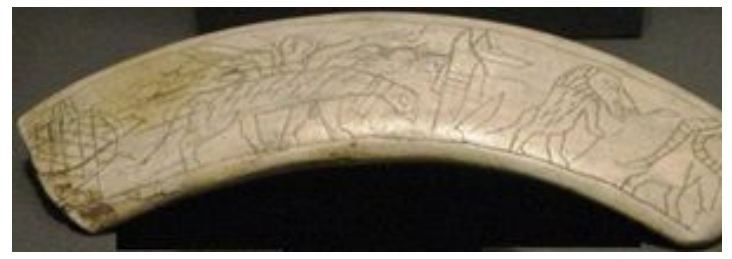

no. 12

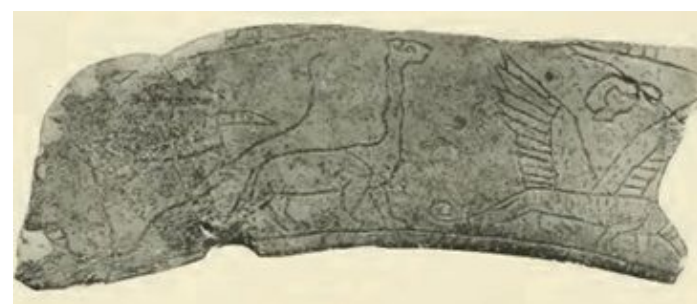

no. 14

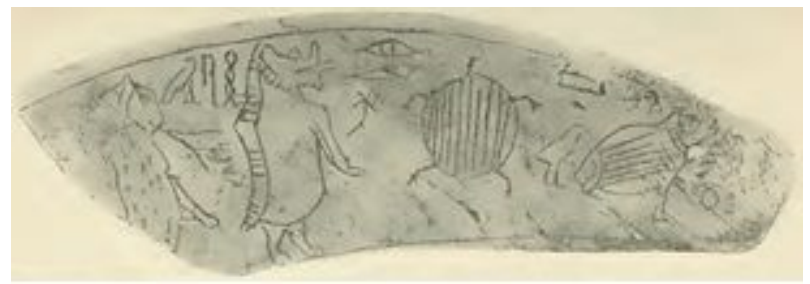

no. 15

cf. (9) Leeman, D. (2019). Apotropaic Wands of the Middle Kingdom, Australia, p.6; (10) Museum of Fine Art Boston Online; (11) Ftzwilliam Museum Online; (12) https://www.pinterest.com.au/pin/ 405886985140287856/ (Accessed on 12 Apri 2020); (13) Loud, G. (1952). Mefiddo - seasons of 1935-39, vol.ii, University of Chicago, Oriental Institute Publication, vol.62, Cambridge University Press, London, , pl.203; (14) Legge, F. "The Magic ivories of the Middle Empire," pl.3, fig.52; (15) Legge, F. "The Magic vories of the Middle Kingdom, part ii" pl.3, fig.48. 